PERCENTAGe DECRease OF INORganic PHOSPHORUS (MEAN VALUES)*

\begin{tabular}{|c|c|c|c|c|c|c|c|}
\hline \multirow[b]{2}{*}{$\begin{array}{l}\text { Muscle of } 10 \\
\text { normal rats }\end{array}$} & \multirow{2}{*}{$\begin{array}{c}\begin{array}{c}\text { After } \\
\text { minutes }\end{array} \\
\begin{array}{r}7 \\
15 \\
30\end{array}\end{array}$} & \multicolumn{2}{|c|}{$\begin{array}{l}\text { Without } \\
\text { addition } \\
\% \sigma \sigma\end{array}$} & \multicolumn{2}{|c|}{$\begin{array}{l}\text { With } 8 \text { units } \\
\text { insulin } \\
\text { per } 100 \mathrm{gm} \text {. } \\
\% \quad \sigma\end{array}$} & \multicolumn{2}{|c|}{$\begin{array}{l}\text { With } 80 \text { units } \\
\text { insulin } \\
\text { per } 100 \mathrm{gm} . \\
\% \quad \sigma\end{array}$} \\
\hline & & $\begin{array}{l}24 \\
42 \\
65\end{array}$ & $\begin{array}{l}2 \cdot 7 \\
3 \cdot 6 \\
5 \cdot 3\end{array}$ & $\begin{array}{l}22 \\
42 \\
64\end{array}$ & $\begin{array}{l}3 \cdot 3 \\
4 \cdot 0 \\
6 \cdot 4\end{array}$ & $\begin{array}{l}16 \\
32 \\
51\end{array}$ & $\begin{array}{l}3 \cdot 9 \\
4 \cdot 1 \\
5 \cdot 8\end{array}$ \\
\hline $\begin{array}{l}\text { Muscle of } 8 \\
\text { alloxan-dia- } \\
\text { betic rats }\end{array}$ & $\begin{array}{r}7 \\
15 \\
30\end{array}$ & $\begin{array}{l}22 \\
41 \\
63\end{array}$ & $\begin{array}{l}2 \cdot 2 \\
7 \cdot 9 \\
5 \cdot 3\end{array}$ & $\begin{array}{l}21 \\
41 \\
62\end{array}$ & $\begin{array}{l}2 \cdot 1 \\
5 \cdot 0 \\
9 \cdot 0\end{array}$ & $\begin{array}{l}16 \\
32 \\
49\end{array}$ & $\begin{array}{l}1 \cdot 7 \\
4 \cdot 0 \\
7 \cdot 2\end{array}$ \\
\hline $\begin{array}{l}\text { Liver of } 10 \\
\text { normal rats }\end{array}$ & $\begin{array}{r}7 \\
15 \\
30\end{array}$ & $\begin{array}{l}11 \\
21 \\
32\end{array}$ & $\begin{array}{l}1 \cdot 4 \\
2 \cdot 0 \\
3 \cdot 2\end{array}$ & $\begin{array}{l}11 \\
21 \\
32\end{array}$ & $\begin{array}{l}0 \cdot 8 \\
1.8 \\
2 \cdot 2\end{array}$ & $\begin{array}{r}8 \\
18 \\
24\end{array}$ & $\begin{array}{l}1 \cdot 1 \\
1 \cdot 6 \\
2 \cdot 6\end{array}$ \\
\hline $\begin{array}{l}\text { Liver of } 8 \\
\text { alloxan-dia- } \\
\text { betic rats }\end{array}$ & $\begin{array}{r}7 \\
15 \\
30\end{array}$ & $\begin{array}{l}10 \\
21 \\
30\end{array}$ & $\begin{array}{l}2 \cdot 5 \\
4 \cdot 6 \\
3 \cdot 4\end{array}$ & $\begin{array}{l}11 \\
20 \\
31\end{array}$ & $\begin{array}{l}2 \cdot 1 \\
3 \cdot 0 \\
5 \cdot 2\end{array}$ & $\begin{array}{r}8 \\
16 \\
23\end{array}$ & $\begin{array}{l}1 \cdot 5 \\
2 \cdot 7 \\
2 \cdot 8\end{array}$ \\
\hline
\end{tabular}

$$
* \sigma= \pm \sqrt{\frac{\varepsilon d 2}{n(n-1)}}
$$

Thus (1) glycogen-phosphorylation by muscle and liver is not increased in alloxan-diabetic rats as compared with normal rats; (2) insulin has in very high doses (of 80 units/100 gm.) a depressing effect on glycogen phosphorylation with muscle and liver of normal animals; (3) there is no difference between the action of insulin in the glycogen phosphorylation of alloxan-diabetic and that in normal animals.

D. STAEHEIIN

Physiological Laboratory, University of Basel.

2 Nature, 158, 588 (1946).

\section{Decrease in the Arginase of the Liver and Mammary Gland in Adrenalectomized Lac- tating Rats as Compared with Pair-fed Controls}

Adrenalectomy causes a decrease in the arginase activity of the liver ${ }^{1,2}$ and lactating mammary gland ${ }^{2}$ in the rat. These findings, together with complementary observations on the abilities of various adrenal cortex steroids to restore tho depleted tissue arginase levels after adrenalectomy $y^{1,2}$, are of great interest in view of the fact that it is now believed ${ }^{3}$ that certain cortical hormones promote gluconeogenesis from protein, a process entailing deamination of amino-acids and the excretion of the nitrogen as urea through the ornithine cycle which, of course, involves the action of arginase.

Adrenalectomy is usually followed by a reduction in food intake 4 , and it is obviously desirable to show that the changes in tissue arginase levels following adrenalectomy are not secondary consequences of this anorexia. We have essayed to do this by means of the paired-feeding technique.

Fifteen pairs of lactating rats were used, one member of each being adrenalectomized on the fourth day of lactation, the other being subjected to a sham operation. Thereafter the daily food intake of each sham-operated control was restricted to that of its adrenalectomized partner. The rats were killed on the seventeenth day of lactation and the arginase activities of the livers and mammary glands estimated as described previously ${ }^{5}$, but using an improved method for arginase determination similar in principle to the colorimetric method of Van Slyke and Archibald $^{8}$. The present arginase units thus differ from those used in our previous publications ${ }^{2}, 5$.

The mean liver arginase activity per gm. moist tissue for the adrenalectomized rats was $170 \pm 13 \cdot 7$ units as compared with $770+25 \cdot 3$ for the pair-fed controls. For mammary tissue the values were $8.4 \pm 0.58$ and $46.4 \pm 2.48$ units respectively: Differences of a similar order were observed when the results were calculated on a basis of total arginase activity per $100 \mathrm{gm}$. rat. There can be no possibility that these differences were due to changes in the activation of the enzyme, since parallel estimations of arginase activated fully by manganese sulphate revealed similar differences, though the arginase activities were now some four to five times higher.

The interpretation of the results of experiments involving the equalized food intake technique may often be more difficult than appears at first sight, particularly as in the present instance, when reduction of the food intake of the controls (which suffered a much greater loss in body-weight than their adrenal. ectomized partners) led to increased tissue protein catabolism, in face of which the liver arginase levels might tend to be maintained ${ }^{7}$. But the present results do show that the anorexia resulting from adrenalectomy is not the direct cause of the reduction in the tissue arginase levels which follows this operation. It must be noted that neither these experiments nor their predecessors ${ }^{1.2}$ give any information as to whether or not the adrenal cortex exerts a direct effect on tissue arginase.

These experiments, which belong to a series in which Messrs. A. T. Cowie and T. H. French also collaborated, will be reported in more detail elsewhere.

S. J. Follex

A. L. Greenbaum

National Institute for Research in Dairying, University of Reading. July 16.

${ }^{1}$ Fraenkel-Conrat, H., Simpson, M. E., and Evans, H. M., J. Biol. Chem., 147, 99 (1943).

${ }^{2}$ Folley, S. J., and Greenbaum, A. L., Biochem. J., 40, 46 (1946).

${ }^{3}$ Long, C. N. H., Katzin, B., and Fry, E. G., Endocrin., 26, 309 (1940).

"Ingle, D. J., in "The Chemistry and Physiology of Hormones", Pub. of Amer. Assoc. Adv. Sci., Washington, D.C. (1944), 83.

- Folley, S. J., and Greenbaum, A. L., Biochem. J., 41, 261 (1947).

Van Slyke, N.D., and Archibald, R. M., J. Biol.Chem., 165, 293 (1946).

${ }^{2}$ Takehara, H., J. Biochem. (Tokyo), 28, 309 (1938).

\section{Shock-induced Stomatal Movements}

IT is now usual in stomatal investigation to affix a porometer cup by lightly clamping the leaf between a glass plate and a glycerol-gelatin washer greased with a beeswax-'Vaseline' luting-wax; this is in essence the method used by Heath ${ }^{1}$ in his criticalstudy of the resistance porometer. As is well known, the mechanical shock attendant on the fixing of such a cup induces almost instantaneous partial closure of the stomata in certain plants, of which Pelargonium zonale is one. The typical effect is shown in the accompanying figure: Record $A$, from the beginning of the record to the point II. This represents the 'recovery curve' of the stomata of $P$. zonale in continuous light after the attachment of a porometer cup, taken with a simple form of resistance porometer ${ }^{2}$; increasing manometer pressure corresponds to stomatal closure. It has for long been assumed that this smooth opening curve does, in fact, represent 'recovery', and that when the stomatal resistance has fallen to a conveniently low value (one to two hours being usually allowed) the stomata may be assumed to be in a substantially normal state. However, in the course of an investigation into the characteristics of shock-induced movements, an unexpected phenomenon has been en- 